\section{Destaque Biográfico}

Recebido em: 05 fevereiro 2021; Revisto em: 07 fevereiro 2021; Aceite em: 07 fevereiro 2021

\section{Biographical Note}

Received: 2 March 2021; Revised: 4 March 2021; Accepted: 6 March 2021

José João Baltazar Mendes é Presidente da Cooperativa de Ensino Superior Egas Moniz desde 2017, tendo como alicerce do seu plano estratégico o respeito e admiração pela herança histórica do seu antecessor e mentor, o Professor Martins dos Santos. Tem conduzido esta Instituição, em conjunto com a sua equipa, com uma visão assente nos pilares da Educação, Investigação, Internacionalização e Interação com a Comunidade.

No que diz respeito à sua formação académica, é licenciado em Medicina Dentária pelo Instituto Superior de Ciências da Saúde Egas Moniz (1995), Pós-Graduado em Implantologia com passagem por Espanha e Suiça, e em Gestão de Unidades de Saúde pela Universidade Católica Portuguesa (2002) e Doutorado em Ciências Biomédicas pelo Instituto de Ciências Biomédicas Abel Salazar da Universidade do Porto (2010).

Desde 2010, é Diretor Clínico da Clínica Dentária Egas Moniz e, desde Janeiro de 2017, também o de Presidente do Centro de Investigação Interdisciplinar Egas Moniz (CiiEM), para além de ter sido convidado para Editor de Secção do European Journal of Dentistry.

No percurso académico em ensino superior, foi designado Professor Auxiliar de Dentisteria Conservadora, em 1995, de Fisiologia Humana, em 1998, de Clínica Dentária Integrada, em 2007 e de Terapêutica Médico Dentária, em 2020. Em 2019, através de concurso, passou a Professor Associado do Instituto Universitário Egas Moniz (IUEM). Desde 2007, integra a Comissão Cientifica do Mestrado Integrado em Medicina Dentária (MIMD) do IUEM e, desde 2017, o Conselho Cientifico do IUEM. Concomitantemente, desempenha funções na Assembleia Geral da Rede Académica de Ciências da Saúde da Lusofonia (RACS), como Vice-Presidente. É administrador do Madan Parque e incorpora a Direção da Associação Portuguesa de Ensino Superior Privado (APESP).

$\mathrm{Na}$ carreira de Saúde Militar do Exército Português, frequentou vários cursos, dos quais se destaca a frequência do Curso de Promoção a Oficial Superior (CPOS) do Instituto

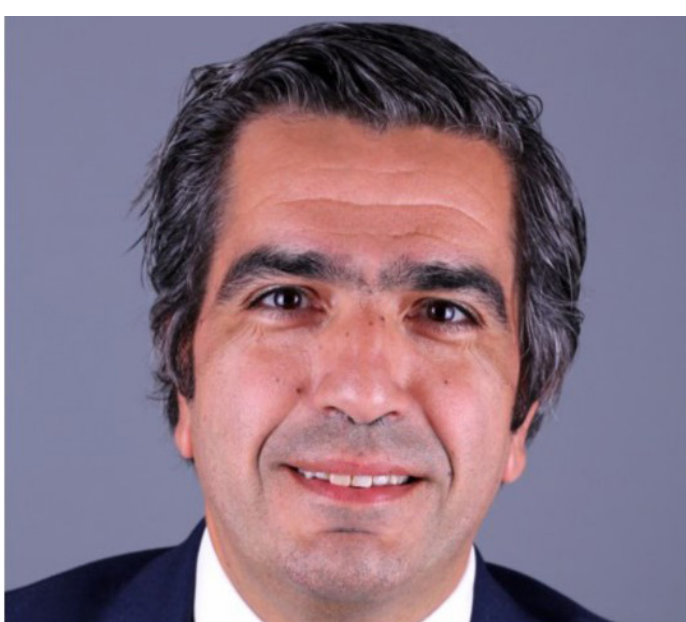

\section{Prof. José João Mendes, PhD}

Coeditor de Ciências Dentárias da RevSALUS Presidente da Direção da Egas Moniz e do Centro de Investigação Interdisciplinar Egas Moniz (CiiEM)

Email:jmendes@egasmoniz.edu.pt

José João Baltazar Mendes has been the President of Egas Moniz - Cooperativa de Ensino Superior, CRL since 2017; the foundation of his strategic plan is based on the respect and admiration for the heritage of his predecessor and mentor Professor José Martins dos Santos. He is leading this institution, together with his team, with a vision based on the pillars of education, research, internationalization and interaction with the community.

Regarding his academic background, President Mendes received a degree in Dental Medicine from the Instituto Superior de Ciências da Saúde Egas Moniz (1995), a postgraduate degree in Implantology, studying in Spain and Switzerland, an MSc in the Management of Health Units from the Catholic Lisbon School (2002) and a PhD in Biomedical Sciences from the Instituto de Ciências Biomédicas Abel Salazar of the University of Porto (2010).

He has been the Clinical Director of the Egas Moniz Dental Clinic since 2010 and the President of the Egas Moniz Interdisciplinary Research Center (CiiEM) since January 2017, in addition to being invited to be Section Editor of the European Journal of Dentistry.

In his academic career in higher education, President Mendes was appointed Assistant Professor of Conservative Dentistry in 1995, of Human Physiology in 1998, of the Integrated Dental Clinic in 2007, and of Dental Medical Therapeutics in 2020. In 2019, through a competitive examination, he became an Associate Professor at the Instituto Universitário Egas Moniz (IUEM). Since 2007, he has been voted as a member of the Scientific Committee of the Integrated Master's Degree in Dental Medicine (MIMD) of IUEM and has been a member of the Scientific Council of the IUEM since 2017. In addition, President Mendes is the representative for Egas Moniz in the General Assembly of the Academic Network of Health Sciences of Lusofonia (RACS), as Vice-President. He is on the Board of Madan Parque and the Board of the Portuguese Association for Private Higher Education (APESP).

In his military career in the Portuguese Army, he attended 
de Estudos Superiores Militares (IESM) e a promoção a Oficial Superior em 2006, tendo também frequentado outros cursos na Escola Superior de Saúde Militar. Foi nomeado Chefe do Serviço de Medicina Dentária e Estomatologia do Hospital Militar Principal (HMP) em Lisboa entre 2000 e 2013. Entre 2005 a 2013, foi nomeado Chefe do Gabinete de Estudos Técnicos (GET) do HMP e Coordenador do MIMD da Academia Militar.

Entre 1997/98 incorporou o Destacamento Sanitário 7 na Missão de Observação das Nações Unidas (MONUA), em Angola, criada pela Resolução 1118 do Conselho de Segurança das Nações Unidas, tendo trabalhado como médico dentista da Organização das Nações Unidas (ONU) em teatro operacional no Hospital de Campanha do Ministério da Defesa Nacional, projetado em Luanda.

Em 2010 foi eleito Vogal do Conselho Científico da Ordem dos Médicos Dentistas (OMD) e, em maio de 2017, Membro do Conselho Geral, findo mandato em 2020.

Globalmente é autor e co-autor mais de 50 artigos indexados na Scopus, é co-editor para as Ciências Dentárias da Revista Científica Internacional da Rede Académica das Ciências da Saúde da Lusofonia, orientador/co-orientador de mais de 33 teses de mestrado e, atualmente, orientador de 5 projetos de doutoramento.

As suas áreas primordiais de investigação são a Epidemiologia e Saúde Pública Oral (especializado em Periodontologia), Inter-relação da Saúde Oral com Saúde Sistémica, Materiais Dentários e Inovação Pedagógica em Medicina Dentária.

Dos vários artigos publicados na área da periodontologia, salienta-se o trabalho de associação entre o ruído de baixa frequência (RBF) e a periodontite, publicado em 2014, como contributo para uma linha de investigação importante no CiiEM, no âmbito da Saúde Ambiental. O artigo, Noise rich in low frequency components, a new comorbidity for periodontal disease? An experimental study, foi inclusive escolhido como destaque de capa no $J$ Indian Soc Periodontol ${ }^{1}$ Destaca-se mais recentemente, o trabalho pioneiro que foi desenvolvido na Saúde Periodontal na população Portuguesa, com os resultados publicados, em 2018, na prestigiada Scientific Reports ${ }^{2}$. Nesta mesma revista, publicou ainda outros dois importantes trabalhos relativamente ao impacto da nova classificação da Periodontologia ${ }^{3}$ e o impacto da periodontite com patologias do trato genital feminino ${ }^{4}$. Paralelamente, tem contribuído para o conhecimento da saúde periodontal em adultos ${ }^{5} \mathrm{e}$ idosos ${ }^{6}$, na sua relação com a hipertensão arterial ${ }^{7}$, com a utilidade do diagnóstico radiográfico periodontal com recurso a ortopantomografias apenas para fins epidemiológicos e de rastreio público ${ }^{8}$. Num outro prisma, o seu grupo validou na área forense, o Índice de $3^{\circ}$ Molar para fins de averiguação da idade legal adulta na população Portuguesa ${ }^{9}$, também na prestigiada Scientific Reports. Também, tem colaborado intensamente na área da inovação pedagógica em Medicina Dentária, com projetos, p.e. de criação de ferramentas de realidade virtual para auxiliar na aprendizagem da colocação de implantes ${ }^{10}$. Finalmente, e no âmbito da atual pandemia mundial, incorporou grupo de estudo que demonstrou, através de um trabalho de revisão, a validade científica de amostras salivares na detecção do SARS-CoV-2 através de RT-PCR. several courses, among which included the Course for Promotion to Senior Officer (CPOS) of the Institute of Superior Military Studies (IESM) and the course for Promotion to Senior Officer in 2006, attending additional courses at the Escola Superior de Saúde Militar. He was appointed Head of the Dental Medicine and Stomatology Service at the Main Military Hospital (HMP) in Lisbon from 2000 to 2013. From 2005 to 2013, he was appointed Head of the Technical Studies Office (GET) of the HMP and Coordinator of the MIMD of the Military Academy.

Between 1997/98, he incorporated Sanitary Detachment 7 in the United Nations Observation Mission (MONUA) in Angola, created by Resolution 1118 of the United Nations Security Council, working as a dentist for the United Nations (UN) in theatre operational at the Ministry of National Defence Field Hospital, designed in Luanda.

In 2010, he was elected Member of the Scientific Council of the Portuguese Dental Association (OMD) and, in May 2017, as Member of the General Council, ending in 2020.

Globally, President Mendes is the author and co-author of more than 70 articles indexed in Scopus; co-editor for the Dental Sciences of the International Scientific Journal of the Lusofonia Health Sciences Academic Network; advisor/co-advisor of more than 40 master's theses; and, currently, the supervisor of $5 \mathrm{PhD}$ projects.

His main areas of research are epidemiology and oral public health (specializing in periodontology), the interrelation of oral health with systemic health, dental materials and pedagogical innovation in dental medicine.

Of his various articles published in the field of periodontology, the work of the association between lowfrequency noise (RBF) and periodontitis, published in 2014, stands out as a contribution to an important line of research at CiiEM, in the scope of environmental health. The article, 'Noise rich in low frequency components, a new comorbidity for periodontal disease? An experimental study' was even chosen as a cover highlight in the J Indian Soc Periodontol'. More recently, his pioneering work that was developed in Periodontal Health in the Portuguese population stands out, with the results published in the prestigious Scientific Reports in 20182. In this same journal, President Mendes also published two other important works regarding the impact of the new classification of periodontology ${ }^{3}$ and the impact of periodontitis with pathologies of the female genital tract ${ }^{4}$. At the same time, this work has contributed to the knowledge of periodontal health in adults ${ }^{5}$ and elderly people ${ }^{6}$, regarding its relationship to arterial hypertension ${ }^{7}$, and the usefulness of periodontal radiographic diagnosis using orthopantomography only for epidemiological and public screening purposes ${ }^{8}$. From another perspective, in the forensic field his group validated the Third Molar Index for investigation of the legal adult age in the Portuguese population ${ }^{9}$, which was also published in the respected Scientific Reports journal. In addition, he has intensively collaborated in the pedagogical innovation of dentistry, with projects such as the creation of virtual reality tools to aid learning ${ }^{10}$. 


\section{REFERÊNCIAS/REFERENCES}

Baltazar Mendes JJ, Oliveira PA, Brito J, Neves Águas AP, Martins dos Santos JM.Noise rich in low frequency components, a new comorbidity for periodontal disease? An experimental study. J Indian Soc Periodontol 2014;18:503-7. Available from: http://hdl. handle.net/10400.26/8170

Botelho J, Machado V, Proença L, Alves R, Cavacas MA, Amaro L, et al. Study of Periodontal Health in Almada-Seixal (SoPHiAS): a crosssectional study in the Lisbon Metropolitan Area. Sci Rep. 2019;9(1). Available from: http://hdl.handle.net/10400.26/33717

Botelho J, Machado V, Proença L, Mendes JJ. The 2018 periodontitis case definition improves accuracy performance of full-mouth partial diagnostic protocols. Sci Rep [Internet]. 2020 Dec 27;10(1):7093. Available from: http://www.nature.com/articles/ s41598-020-63700-6

Escalda C, Botelho J, Mendes JJ, Machado V. Association of bacterial vaginosis with periodontitis in a cross-sectional American nationwide survey. Sci Rep [Internet]. 2021;11(1):1-9. Available from: https://doi.org/10.1038/s41598-020-79496-4

Machado V, Botelho J, Proença L, Alves R, Oliveira MJ, Amaro L, et al. Periodontal status, perceived stress, diabetes mellitus and oral hygiene care on quality of life: A structural equation modelling analysis. BMC Oral Health. 2020;20(1):1-11.

Botelho J, Machado V, Proença L, Oliveira MJ, Cavacas MA, Amaro L, et al. Perceived xerostomia, stress and periodontal status impact on elderly oral health-related quality of life: findings from a crosssectional survey. BMC Oral Health [Internet]. 2020;20(1):199. Available from: https://bmcoralhealth.biomedcentral.com/ articles/10.1186/s12903-020-01183-7

Machado V, Aguilera EM, Botelho J, Hussain SB, Leira Y, Proença L, et al. Association between Periodontitis and High Blood Pressure: Results from the Study of Periodontal Health in Almada-Seixal (SoPHiAS). J Clin Med. 2020;9(5):1585.

Machado V, Proença L, Morgado M, Mendes JJ, Botelho J. Accuracy of Panoramic Radiograph for Diagnosing Periodontitis Comparing to Clinical Examination. J Clin Med. 2020;9(7):2313.

Albernaz Neves J, Antunes-Ferreira N, Machado V, Botelho J, Proença L, Quintas A, et al. Validation of the Third Molar Maturation Index $(1<\inf >3 \mathrm{M}</$ inf $>)$ to assess the legal adult age in the Portuguese population. Sci Rep. 2020;10(1).

Zorzal ER, Paulo SF, Rodrigues P, Mendes JJ, Lopes DS. An immersive educational tool for dental implant placement: A study on user acceptance. Int J Med Inform [Internet]. 2021 Feb;146:104342. Available from: https://linkinghub.elsevier.com/retrieve/pii/ S1386505620306705. 